\title{
THE COFFEE CAPSULES CONSUMPTION PRACTICE
}

\section{A PRÁTICA DE CONSUMO DE CAFÉS EM CÁPSULA}

Recebido em 17.01.2017. Aprovado em 24.04.2018

Avaliado pelo sistema double blind review

DOI: http://dx.doi.org/10.12712/rpca.v12i2.1195

\section{Rodrigo Marçal Gandia}

Universidade Federal de Lavras (UFLA), Lavras/MG, BRASIL

romgandia@gmail.com

\section{Cassiano de Andrade Ferreira}

Universidade Federal de Lavras (UFLA), Lavras/MG, BRASIL

cassianoferreira99@hotmail.com

\section{Elisa Reis Guimarães}

Universidade Federal de Lavras (UFLA), Lavras/MG, BRASIL

elisarguimaraes@gmail.com

\section{Joel Yutaka Sugano}

Universidade Federal de Lavras (UFLA), Lavras/MG, BRASIL

joel.sugano@gmail.com

\section{Daniel Carvalho de Rezende}

Universidade Federal de Lavras (UFLA), Lavras/MG, BRASIL

rezendedc@gmail.com

\begin{abstract}
Changes in consumer behavior and his constant search for convenience and practicality in products and services stimulated the demand for coffee capsules, a fast growing market in Brazil. However, little is known about consumer behavior and preferences regarding this product, motivating this study. Our aim was to understand the coffee capsules consumption through the lens of the Theory of Practice, in order to analyze the specificities that structure this market and guide the behavior of its consumers. Through a qualitative and descriptive study, supported by the conduction of semi-structured interviews and participant observation in virtual groups of these product's consumers, we found that the consumption of encapsulated coffees is conditioned to the disposition of time and company of the interviewees and that the product's quality perception is still low. In addition, there is great resistance to the acquisition and consumption of generic capsules.
\end{abstract}

Keywords: Coffee in capsules. Consumer behavior. Practice Theory

\section{Resumo}

Mudanças no comportamento do consumidor e sua constante busca por conveniência e praticidade em produtos e serviços estimularam a demanda por cafés em cápsula, mercado em rápido crescimento no Brasil. Contudo, ainda pouco se sabe sobre o comportamento e preferências dos consumidores desse produto, motivando a realização deste estudo. Objetivouse compreender o consumo de café em cápsulas sob a ótica da teoria da prática, a fim de analisar as especificidades que estruturam esse mercado e orientam o comportamento de seus consumidores. Por meio de estudo qualitativo e descritivo, apoiado na condução de entrevistas semiestruturadas e observação participante em grupos virtuais de consumidores destes produtos, constatou-se que o consumo do café em cápsulas está condicionado à disposição de tempo e companhia dos entrevistados e que, ainda, é baixa a percepção de qualidade do produto. Ademais, nota-se grande resistência à aquisição e consumo de cápsulas genéricas.

Palavras-chave: Café em cápsulas. Comportamento de consumo. Teoria da Prática. 


\section{Introduction}

In recent years, there was an intense change in consumption behavior motivated by a range of external factors related to the massification of information and globalization. Thus, the consumer, usually perceived as a simple and rational decision maker, is now considered a complex and oftenunpredictable individual, who is immersed in different cultural and social networks and whose decisions acquire an important subjective dimension. The food market is a representative example of this fact, since it emerges as a sign of the transformations of a world in which food, as an essential resource for life, acquires another meaning. Lowe, Bocarsly and Parigi (2008) argue that food consumption has never meant only to satisfy physical hunger, since quantity, frequency and choice of food are affected by several other variables, such as appetite, cost, accessibility, culture, nutritional values, emotions, among others. This is part of what Fonseca, Souza, Frozi and Pereira (2011, p. 3415) define as food modernity: a "historical moment in which various changes occur around the food system in the contemporary context". The food industry must be alert to the trends and challenges of this new demand scenario as a way to maintain its competitive position.

With increasing income and purchasing power, in addition to greater access to information, the challenge will be to produce goods meeting the demands of a consumer that is increasingly critical about all factors related to food industry (Federação das Indústrias do Estado de São Paulo [FIESP] \& Instituto de Tecnologia dos Alimentos [ITAL], 2010). Dagevos and Van Ophem (2013) complement that the food market must evolve into a consumer-oriented one, since the modern consumption society challenges the traditional segmentation models.

Currently, the international coffee capsule (monodoses) market growth stands out as an example of this adaptation to modern food consumption. According to Euromonitor data, Brazil stands out as the main coffee capsule market in South America, with 3.6\% of the total value of retail sales in capsules in 2014 (Euromonitor, 2015). Also, the capsule market is expected to grow 80\% until 2019 (Abic, 2016).

In this context, the capsule coffee market points out to a consumer willing to find in coffee, characteristics that overcome the simple fact of ingesting a food product. Gandia, Sugano, Vilas Boas, Ferreira \& Gomes (2016) state that capsule beverage users generally seek practicality and quality in this product's consumption. These characteristics meet the precepts established for food modernity, which according to the technical report prepared by FIESP and ITAL (2010), the convenience and practicality are, above everything else, the main priorities of Brazilian consumers, followed by food reliability and quality (Gandia et al., 2016).

To understand this burgeoning market, we draw from the theory of practice, which focus on a specific practice (in our case, the encapsulated coffee consumption) and the way it is established, turning the consumer into a secondary source of analysis. That is, the collective behavior of social actors becomes the main object of study, being more important than the individual consumption act (Warde, 2005). Reckwitz (2002) defines the theory of practice as a cultural theory, a smaller unit of social analysis in practices, being understood as a type of behavior that can be used in various interconnected elements: corporate and mental enterprises, such as understanding and knowledge, emotional states and motivation. Thus, we consider that the proposals for coffee capsules consumption are inserted more in behaviors linked to daily life than in individual choices. In this view, this paper aims at identifying the practices of the capsule coffee consumers, in order to analyze the specifics that structure this market and guide the consumption patterns. A better understanding of coffee capsules, focused on practice around the product, can help the elaboration of business strategies better aligned with its target audience, thus contributing to the expansion and profitability of this market.

\section{Theoretical Framework}

\section{Theory of practice and consumption studies}

Despite the vast field of consumption theories constructed so far, studies are very scattered, specific to the areas they propose to address, and there is not an established theory about practice linked to consumption (Warde, 2005). However, such a theory has been recently gaining room in the field of applied social science studies, especially in the areas of marketing and consumer behavior (Borelli, 2014).

Heterogeneity is a hallmark of the theory of practice and its main purpose is to coordinate understandings of what drives people to consume a particular good or service based on their habits (Warde, 2005). That is, it is a kind of inverted logic of consumption analysis in which, instead of evaluating general consumption or specific products and services, habits and its impacts on consumption are analyzed.

Several authors have been interested in studies about the theory of practice. Among the main ones are Rechwitz (2002), Schatzki (2001), Giddens, Bourdieu, Lyotard and Charles Taylor (Warde, 2005). According to Warde 
(2005), Giddens was one of the first "practice theorists". Giddens (2009) described the society as a composition of social practices reproduced through time and space. Contrary to some scholars' claims, he argued that the focus of the practice theory is not the experience of an individual, nor is it a form of social totality, but rather the interactions between individuals and the social structure, which, according to Hargreaves (2008), generate socially recognizable practices.

Social practices do not have a uniform plan where agents behave in the same way. An individual's behavior is guided by its previous experiences, values, level of knowledge, among others. Thus, differentiation occurs within a practice, being individuals differentiated as the youngest and the most experienced, visionaries and followers, professionals and amateurs, etc., each playing its own role and occupying a different position within the practice (Warde, 2005).

Like Warde (2005), Bourdieu (1984) also identified differentiations within practices. According to his studies, there are distinct social functions, classifications, assimilations, positions and rewards within a same practice, which can have different meanings if you change the observation group, time, or place. Also, the historical development of a practice has its differentiation conditioned by the social context, the dominant modes of economic exchange, the culture and tradition (Warde, 2005).

\section{Theory of practice as a tool to study the consumption culture}

In order to recognize the social construction of a practice, the importance of its exercise, its power formation and the conduct of social actors, one must understand the sociological questions of "why" and "how" people do it. The answers will necessarily be historical and institutional. This is the starting point for understanding the capacity, competence and collective learning of a practice (Warde, 2005).

Reckwitz (2002) provides a simple and objective explanation of the difference between practice and theory of practice, as follows:

"Practice (Praxis) in the singular represents merely an emphatic term to describe the whole of human action (in contrast to 'theory' and mere thinking). Practices, in the sense of the theory of social practices, however, is something else. A 'practice' (Praktik) is a routinized type of behavior, which consists of several elements, interconnected to one other: forms of bodily activities, forms of mental activities, 'things' and their use, a background knowledge in the form of understanding, know-how, states of emotion and motivational knowledge"

(Reckwitz, 2002, p. 249).

The act of consumption takes place within a practice, since the modes and contents of appropriation of goods and services are elements of a practice (Hargreaves, 2008; Warde, 2005). So far, practices will be understood through the moments of consumption they foster (Warde, 2005).

According to Gronow and Warde (2001), the theory of practice has been incorporated into empirical studies of consumption from the late 90s, through a growing analytical approach of individuals' everyday life. Its approach is different from the conventional ones that study the culture of consumption because, besides studying the factors that lead to individual choices of consumption, it encompasses cultural and group structures that are beyond consumers' reach. Therefore, it contributes to a voluntary and structuralist analysis of consumption (Halkier \& Jensen, 2011).

The patterns of similarity and difference of consumption, possessions, and use within and between groups of people should be seen as a deductive linking of how the practice is organized, not as the result of personal choice, whether unrestricted or limited (Swann, 2002). Moreover, the specific items implanted and consumed are closely interconnected and sometimes defining elements of a practice (Warde, 2005).

Corroborating this thought, Borelli (2014) affirms that the origin of the consumption is in the practices. People consume through the social practices in which they are involved. "Therefore, it is the participation of the individual in a particular practice that explains the nature and processes of consumption, not a personal decision limited by structural forces" (Borelli, 2014, p.23). Consumption becomes a component part of this practice. Thus, consumption behavior has a direct connection with the social organization of practices and with the behavioral changes of its practitioners (Hargreaves, 2008). 


\section{The capsule coffee market in Brazil and worldwide}

The capsule coffee market is a segmentation of products characterized by the preparation in monodoses, available in sachets and capsules. Even with the current presence of the coffee sachets, capsules are responsible for the greatest current demand. According to Gandia et al. (2016), although coffee capsules are no longer something innovative in the global market, the business models oriented to this product, in the Brazilian market, play an important role due to the intense expansion in the last years.

The consumption of portioned coffees has grown over $20 \%$ in recent years, although they still occupy the lowest market share of the coffee segment (Santos, Araújo, França \& Paula, 2015). According to these authors, the habit of consuming coffee capsules, sachets or roasted beans for using in automatic machines, which are already widely used in European countries, has become increasingly common among Brazilian consumers.

Among the main factors that stimulate coffee capsules consumption, are practicality, easiness, speed and convenience (Martins, 2013; Carrêlo, 2014; Gandia et al, 2016), quality (Carrêlo, 2014, Gandia, 2016) and machine attributes, such as design (Martins, 2013). The promise of practicality offered by the capsule system consists of offering a quality beverage by only inserting a desirable flavor capsule, in a compatible machine, and pushing a button.

The single cup market is not restricted to the capsule product. Manufacturers also provide the consumer with a range of add-ons to extend the product consumption experience. Martins (2013) points out that Nespresso stands out in the diversification of complementary products, such as cups, support for capsules, storage boxes and transport bag for the machine, among others.

Regarding the distribution channels, the online sale is present in all representative brands of the national market. About the other channels, it is worth noting that the retail serves most of the brands in the current market, though Nespresso, a pioneer in capsules in the international market, restricts its commercialization to online venues or its specialized branded boutiques, strategically placed in the most prestigious spots in the main capital cities around the world.

According to Euromonitor (2014) data, coffee capsule's consumption has increased over the past few years, especially in European countries, such as Austria (30.7\%), Belgium (37.8\%), Ireland (30.9\%), Spain (47.2\%), France
(53.1\%), Switzerland (41.4\%), Netherlands (50.7\%) and Portugal, where $69.2 \%$ of the consumed coffee in the country come from capsules. North America, Canada and the USA are the major potential markets for the product, presenting respectively $46.5 \%$ and $31.3 \%$ of participation of the capsules in retail. It is interesting to note the fast market penetration of coffee capsules in the last years, as in the USA, which had only $4 \%$ of retail penetration in 2009 , and increased over $277 \%$ in five years.

In South America, the main capsule-consuming countries are Argentina, Brazil, Chile and Colombia. Brazil stands out as the main market, with a volume of $3.6 \%$ of the total value of retail sales in capsules in 2014, against $2 \%$ in Argentina, 3\% in Chile and only $0.1 \%$ in Colombia. In Brazil, the increase in comparison to the other countries was even more pronounced, experiencing a retail sales growth of 610\% between 2009 and 2014 (Euromonitor, 2014).

Given this context, it is clear that the capsule beverage market has shown exponential growth in recent years, both in the domestic and international market.

\section{Methodology}

This research's qualitative and descriptive approach was chosen because it prioritizes an interpretative vision of reality, from the point of view of individuals and the researched context (Silva, Gobbi \& Simão, 2005). Besides, as defined by Malhotra (2012), we describe the characteristics of a population or phenomenon and establish relationships between them in the specific case of capsule consumers and their consumption practice. One of the characteristics of this type of research is the standardization of techniques for data collection (Gil, 1999). The interview is one of the methods that can be used for communication and data collection about the objects of a descriptive research (Malhotra, 2012).

To collect data, we used the semi-structured interview, a technique indicated to explore the perceptions and opinions of the interviewees about complex, and sometimes, sensitive issues and allows probing for more information and clarification of responses (Barribal \& While, 1994). This choice of design is due to its flexibility and the possibility of quickly adapting the questions.

Data collection occurred in the city of Lavras-MG (Brazil), through the conduction of ten face-to-face interviews, with an average duration of twenty minutes each, and eight interviews by email. The criteria for choosing the 
interviewees was their self-declaration as a consumer of coffee capsules and availability to respond to the questionnaire, either by email or in person. We conducted all interviews during August 2016.

We used the snowball method (Alencar, 1999) to identify new interviewees. The identity of the respondents has been preserved, so they will be treated as interviewee 1 , interviewee 2, 3 and so on. The numbering of the interviewees was random and helped the organization and analysis of the collected material.

We used content analysis to treat and analyze the interviews. This technique allows the identification of intrinsic attributes and structures in the interviewee's discourse, which are important for analysis. This method can be used to understand the meaning of what social actors outsource in their discourse (Mozzato and Grzybovski, 2011).

The data analysis followed the four steps suggested by Bardin (2010), which are: the previous analysis of the material; data organization and systematization; the exploratory analysis, codification and classification of the material regarding the similarity, characteristics and informational value of the ideas brought; and, finally, data interpretation through critical and reflexive analysis of the results.

At the same time, we used the non-participant observation method in three capsule users groups on Facebook, where researchers sought to observe, without interference, reports and practices related to the consumption of encapsulated beverages in the following groups: NESCAFÉ Dolce Gusto, 7,820 members; Dolce Gusto Nestlé "Liberdade de Expressão", 3,585 members, and; Nespresso Nestlé Brazil, 4,326 members. These groups are unrelated to brand owners and only include users who wish to exchange information about the product.

\section{Results and discussions}

\section{General aspects about the interviewees and the research object}

Regarding the profile of the eighteen interviewees, eleven were men and seven women. Their age ranged from 25 to 59 years old, all of them at least began college and twelve of them have postgraduate, master or doctorate degrees. When asked about their occupations, the most frequent profession was university professor, with a third of the respondents. There were also undergraduate and postgraduate students, executives, administrators, geologist, lawyer, social worker, project coordinator, international analyst and software quality analyst.

About the family income, it was used the division and nomenclature criteria established by the "Secretaria de Assuntos Estratégicos" (SAE or Strategic Issues Secretariat) of the Brazilian Federal Government, which has being used since 2014 (Gasparin, 2013). Through this parameter, it can be said that the participants of this research are classified as "Lower high class" (from $\mathrm{R} \$ 4,076$ up to $\mathrm{R} \$$ 9,920) and "Upper high class" (above R $\$ 9,920$ ), since the family incomes informed by them ranged from $R \$ 4,500$ to $R \$$ 25,000 . Seven respondents chose not to answer this question.

When asked about the brand of capsule coffee machine they used, the vast majority of respondents (fifteen) reported using Nespresso machines, while only three of the interviewees used Dolce Gusto machines. Respondents did not mention any other brand.

Table 1 . How long do you consume coffee capsules?

\begin{tabular}{cccccc}
\hline $\mathbf{1}$ year & $\mathbf{2}$ years & $\mathbf{3}$ years & $\mathbf{4}$ years & $\mathbf{5}$ years & $\mathbf{6}$ years \\
\hline 8 & 3 & 3 & 1 & 1 & 2 \\
\hline
\end{tabular}

Source: Elaborated by the authors

As can be seen in the Table 1, there are "older" and "newer" consumers of coffee capsules, within this same practice, which corroborates the theory of differentiation based on aspects such as hierarchy, engagement, time of adhesion, among others, brought by Bourdieu (1984) and ratified by Borelli (2014) and Warde (2005). As the coffee capsule segment is relatively new and is driven by a growing trend in the number of users consuming the beverage (Martins, 2013), it is not surprising that more than half of the interviewed consumers have acquired the habit in the last two years.

Table 2 . Average consumption of coffee in capsules per week

\begin{tabular}{cccc}
\hline $\begin{array}{c}1 \text { to } 4 \\
\text { coffees }\end{array}$ & $\begin{array}{c}5 \text { to } 7 \\
\text { coffees }\end{array}$ & $\begin{array}{c}8 \text { to } 11 \\
\text { coffees }\end{array}$ & $\begin{array}{c}12 \text { to } 15 \\
\text { coffees }\end{array}$ \\
\hline 3 & 6 & 6 & 3 \\
\hline
\end{tabular}

Source: Elaborated by the authors

Most respondents reported consuming this type of coffee in the afternoon or in the morning, with fourteen and 
eleven responses, respectively, while only four reported nighttime consumption. Some interviewees consumed this type of coffee in more than one period of the day, so the sum of the frequencies of answers exceeded the total number of interviewees, which would be eighteen.

According to Warde (2005), the theory of practice tries to identify what leads the individual to consume a particular good or service, based on his habits. In this sense, this paper also tried to understand how did respondents start to consume coffee and if they were influenced by someone, since coffee consumption is the gateway to the practice of consuming coffee capsules.

\section{The consumption of traditional and capsule coffees}

Coffee's appreciation and consumption habit were present in interviewees' lives since their childhood. Fourteen of the eighteen interviewees consumed coffee since childhood, and half of them consumed coffee black and the other half with milk. Usually the mother prepared the coffee, but in a few cases, the father or the grandmother was the one responsible for preparing the beverage. The most frequent moments of coffee consumption were in the morning, with eleven responses, and in the afternoon with seven responses. It is worth considering that four interviewees consumed coffee in the morning and in the afternoon since childhood, while other four began to consume coffee after young or adult.

We verified that most of them started drinking coffee by influence of their family's feeding habits; only four respondents, the same ones who said they did not consume coffee when they were a child, began consuming the beverage in work environment when they were young. A common feature among the respondents is that all of them said they had been influenced by someone and talked about coffee as a social drink, which is often consumed with other people. This corroborates the inference of Hargreaves (2008) that interactions between individuals and the social structure generate socially recognizable practices. It also shows the importance of the dissemination of consumer culture habits among the individuals.

Although the Brazilian keeps an apparent affection to the coffee strainer with a cloth or paper filter, "new products, that preserve and intensify the aroma and flavor of drip coffee, could be thought as alternatives" (Teixeira, 2014, p. 115). In this scenario, coffee capsules emerged and have recently gained a lot of space because of its practicality, easiness and speed, without losing product quality, highly valued features by consumers in these days (Carrêlo, 2014; Gandia et al., 2016; Martins, 2013). This was also mentioned by the interviewees $3,7,14$ and 15 .

When reporting their first experience of using coffee capsules, the interviewees considered the machine or capsule as something new, surprising and innovative. "She had bought the first model of Nespresso that was launched in Brazil [...] it was an event to have coffee at her house" (interviewed 18). "[...] it was very surprising to see it working; I had no idea how it was like" (interviewed 2). "[...] we visited one of her colleagues and her father had acquired a machine [...] it was something almost festive, people watching it, it was different, it was not so common" (interviewed 1). "[...] coffee had an amazing taste" (interviewed 17).

According to interviewee number 13, because of "[...] a machine, the whole experience of drinking coffee has changed". The practicality and speed in coffee capsule preparation, associated to the guarantee of aroma, flavor and quality, is a promising consumption trend in the Brazilian food sector (Gandia et al., 2016). These features were extremely valued by the interviewed consumers.

Only a third of the respondents said that the first coffee capsule experience of consumption influenced the purchase of the machine. Most interviewees bought or won the machine before they have even tried the product. Others reported a bad first consumption experience, just appreciating the product some time later.

The first capsule coffee machines were manual (i.e. the user had to press the button to start and stop the machine) and, according to two interviewees, it was very difficult to find the "ideal point" of coffee, which was sometimes watery, with powder on the bottom and capsules were not always of good quality. Perhaps, these aspects have influenced the interviewees' response about their first experiences of consumption.

Among the respondents, the most common way to prepare coffee was the coffee capsule, with nine responses, followed by the strainer with cloth or paper filter, with seven responses, and two respondents said to use the two forms of preparation with the same frequency. However, we chose people who necessarily consumed coffee capsules to be interviewed. That is, although coffee capsule is a trend in the beverage segment, drip coffee is still the most common form of consumption among Brazilians, as discussed by Teixeira (2014).

Most of the respondents reported that their choice for a coffee preparation method is more influenced 
by the moment and their company than necessarily by the preference of the specific preparation method. For example, drip coffee is prepared in larger dosage, which better suits those who drink a large amount of coffee or when several people are gathered, and it is cheaper. On the other hand, if the person is alone, in a hurry or looking for practicality, coffee capsule is the best option.

In short, there are different occasions, experiences and moments, which means there is no way better than the other. As stated by the interviewees, Teixeira's study (2014) infers that the price of coffee influences on the consumed quantity. Gandia et al. (2016), in turn, confirm that the consumer looking for easiness, convenience and speed found the solution in the capsules.

We observed a weak association between coffee capsules and quality perception: for consumers, capsules are mostly consumed for its practicality and speed. Coffee quality was mainly associated to the chosen brand and the type of coffee. The capsule itself was associated only with the preparation form: "The capsule for me is just a package or preparation method [...]" (interviewee 1).

The interviewees were extremely resistant to generic capsules $^{i}$ consumption, mainly due to bad previous experiences related to coffee flavor and machine operation. Besides, there is little difference in price and they have no interest in consuming this type of product for now. Those who consumed generic capsules earned the product, or consumed it in a sales experience produced by the brand or had complaints related to the experience: "I did not like it very much. I found it so... quite different [...]" (interviewee 10). "I won some to try, but I'm afraid of damaging my machine" (interviewed 16).

"I won one, I do not remember the brand, but the experience was not the same. I observed remnants of the powder in the cup, the machine made a different noise when I used it, it did not get the concentration of Nespresso, it was a little watery, and so, I do not know if it was a specificity of this generic, but after that I would rather not try it again. The experience was not good" (interviewed 1).
"The capsule did not make a very good coffee, it was a coffee with a burnt taste. I have tried several, at least three, and I feel that the coffee is not the way I like. Either it comes with a weird taste or it is very "watery"” (interviewed 6).

Only two respondents reported good experiences with generic capsules: “[...] I found it tasty as well. I bought one named Café Origem and the other I do not remember, but it was delicious too. It had a sweeter taste" (interviewee 5). "The first brand I consumed was Suplicy and it pleased me very much in all respects, not losing for a Nespresso capsule" (interviewed 11).

\section{The searching rite of coffee capsules}

Internet and physical stores (retail or specialty brand boutiques) are the main venues of acquisition, especially for its easiness/practicality, which are exposed in different ways. While some respondents reported online acquisition for its easy access, others prefer physical stores because they are always close to them.

"I buy through the internet, through the Nespresso website. Because I buy straight from Nespresso, I think it is practical [...] I choose and I have the facility to put what I want [...] I can sit here (referring to his chair in the room in front of the computer) and I talk during 15 minutes, oh I do not want this, I want that... take out, move [...] It is easy to be here online, is practical" (interviewed 7).

For the interviewee 7, easiness is being in a comfortable place in his home/office, where, without haste, he can search for his products, a different interpretation from interviewees 9 and 10: "I buy straight from the Nespresso boutique given the easiness, because I always go to Belo Horizonte $^{\mathrm{ii}}$ " (interviewee 9). "I buy at the boutique. I usually go there because I'm always at the Morumbi Malliii" (interviewed 10).

\footnotetext{
${ }^{i}$ Generic capsules are those compatible with Nespresso or Dolce Gusto's machines, but not produced by those brands.

ii Belo Horizonte is the capital city of the southern Brazilian state of Minas Gerais.

iii Morumbi Mall is a shopping mall located in a prestigious neighborhood in São Paulo city.
} 
For interviewees 9 and 10, boutiques became synonymous of shopping convenience, because there is a routine/habit of going to places that are easily accessible to a Nespresso boutique. According to Warde (2005), the reproduction of 'practices as entities' requires constant 'staging'. In this sense, Borelli (2014) concludes that for practice to exist, it must be regularly performed by the individual, what explains the different connotations of easiness for coffee capsule consumption.

Taste is what usually influences the choice of one capsule over another. Only four (2, 6, 7 and 10) among the eighteen interviewees reported technical characteristics (variations of flavors, blends, aromas and intensity) when choosing the product. One characteristic of the capsule market is the presence of a wide variety of blends, one of the dominant attributes in the consumption of encapsulated beverages (Gandia et al., 2016).

Despite the growth in coffee capsules consumption, knowledge and learning engagement in this market are scarce. According to Schatzki (2002), there are internal hierarchies or differentiation within a practice: individuals do not participate in the practices uniformly, since their understandings, procedures and engagements may vary. Although information and stimulus to teaching and learning about its wide range of products, aromas, flavors and intensities are characteristic of the capsule product, we noted that the consumer has often not yet reached a consistent point of engagement. Warde (2005) concludes that people probably learn differently from each other, suggesting that it would be helpful to examine in detail how understandings, procedures, and values of engagement are acquired and adapted into performance. Finally, Bourdieu (1984) states that individuals can use the specific knowledge about a particular subject as a source of differentiation.

\section{Tasting ritual of coffee capsules}

Interviewees often reported a solitary consumption of coffee capsules although there are moments when it is shared with other people. Solitary consumption is associated with facilitating the daily (especially morning) and busy routine, due to its practicality. According to Teixeira (2014), since the 1990s, the habit of early and at home breakfast seems to be changing, assuming new routines, given the convenience and practicality. "I consume the capsules [...] usually in the morning, alone [...] because it is practical, it will be cheaper and faster" (interviewed 6).
On the other hand, collective consumption is mainly appreciated when there are possibilities to please other people or when innovative aspects of the product may surprise:

"I usually consume alone. Group
consumption occurs only when I receive
friends at home. The experience of
consumption in my case is different because
many of my friends do not have the same
habit of drinking coffee as I do, or the
same knowledge, so it is fun to explain the
differences between types of coffee and see
their reactions" (interviewed 18).

We observe that people use this product according to established rules related to their practical understanding of the product in their daily life (interviewees 6 and 18). According to Schatzki (2002), the rules would be formulations, principles, precepts, instructions that command, direct or instruct people to perform specific actions. However, the product (materiality) is still present because the needs of fulfilling aspects related to expectations and mind moods, as mentioned by the interviewee 18 .

All interviewees evidenced having a special place, often called "coffee nook", for their machine, with specific and varied criteria for the organization and accommodation of the capsules (by color, intensity, preferred drinks and even the manufacturer's packaging itself). We observed that this places were intended for the use and preparation of coffee and its beverage variations. It is in this space, usually with a different decoration, that are generally accommodated the machine, capsules, utensils and raw materials for the preparation:

\footnotetext{
"My machine has a special place in my home. I bought a demolition wood trimmer to give a more charming atmosphere, I always store the capsules in an enclosed acrylic cube along with some other decorative accessories that I bought specially to accompany, such as sugar bowl, a cinnamon pot, biscuits and chocolate" (interviewed 15).
}

Shove and Pantzar (2005, p. 45) consider that practices involve the "integration of materials, meanings and forms 
of competence". They seem to highlight the role of materials in the practices' constitution (Gram-Hanssen, 2011). In this case, the consumption practice is stimulated by several factors, i.e. the dedication of a special place (coffee nook) for the machine (always in sight and ready for use) and other related products.

Not only the coffee machine had this role of instigating the practice, but also other artifacts and utensils that complete the experience of coffee capsule consumption:

"I got a wooden box to organize and store the capsules (referring to the Discovery box, marketed by the Nespresso brand itself), so I remove from the packaging that comes from the company and I distribute it there the way I like [...] I like this organization to know if this is finishing [...] it is a way of organizing and knowing how many are there and how many I will need to buy of them (referring to different types of capsules)" (Interviewee 7).

We emphasize that Nespresso not only sells capsules, but also offers a wide range of supplements that extend the experience of tasting their coffee, turning these artifacts into supporting precursors to the consumption. The following excerpt illustrates a passage in which the consumer opted to purchase an artifact (capsule holder) not marketed by the Nespresso brand:

"The capsules are stored in a rotating little tower, from which you remove the capsules from the bottom. It was not bought at Nespresso. I do not remember where I bought it, but I remember it was not that expensive, because the Nespresso ones are very expensive (referring to the utensils and capsule holders marketed by Nespresso)" (interviewed 6).

We observed that the brand instigates consumption through artifacts, but cannot compel them to consumers that look for other alternatives. Warde (2005) argues that, because practices have their own conventions, institutionalized and collectively regulated, somehow they protect individuals from the influence of producers and propagandists. The author completes that it does not mean that producers are mere supporters in the innovation process, but that their successful action is directed at adapting the practices to their interests. Largely, "the effect of production on consumption is mediated" by practices (Warde, 2005, p.141).

The sensations while tasting coffee capsules were associated with product quality, with aroma being one of its main differentials, since, in interviewees' opinion, it is better preserved by being in capsules. "You put the capsule and that specific aroma comes from it... you feel that coffee aroma that is a delight" (interviewee 10).

However, we note that being in the capsule format does not necessarily correspond to superior product quality. Capsules, in many cases, start to play the role of an artifact where practicality and consistency (preparation standard) corroborate with a previous conception of quality, allied to the fact that a preparation in smaller portions (unique dosages) facilitates new consumption experiences.

\begin{abstract}
"I see the capsule more as a practicality and as, in quotation marks, the guarantee of that experience I already know [...] it's more or less like a McDonald's, it may not be the best in the world, but I know how the experience will be" (interviewee 1).
\end{abstract}

Practices have a trajectory, a path of development. The substantive forms that a practice takes will always be conditioned to the specific institutional arrangements of the moment, place and social context in which it is performed (Warde, 2005). In a new food consumption pattern, individuals are subject to constant (mis)information of what is good or bad, which, allied to a total lack of time, makes capsules play an important role within the historical context of coffee consumption.

Most consumers reported a love for the coffee beverage, either because of its stimulating properties, "nostalgic memories" (interviewee 1), beverage features (aromas and flavors) or by everything that coffee brings, i.e. "the pleasure of giving a break" (interviewee 6) that is much related to the beverage, especially in work environments.

However, when asked about the significance of the capsule beverage machine in their lives, most interviewees indicate it only as an instrument of practicality, sometimes comparing it to household utensils, such as a "microwave or refrigerator" (interviewee 9). Nevertheless, in many cases it changed the interviewees' way of consuming 
coffee, pointing to the main implication of the Theory of Practice for the study of consumption, which consists in the fact that the origin of behavior change is the trajectory of development of the practices (Warde, 2005).

\section{Concluding remarks}

We aimed to identify, through the theory of practice, the consumption behavior of coffee capsules, in order to analyze the specifics that structure this market and orient the consumption. Warde (2005) states that consumption occurs within a practice, and presents a distinct perspective, more focused on the collective development of appropriate modes of conduct in everyday life than in the individual choices. Although the theme is recent, several authors have analyzed its use in different objects of study, such as practices of street runners (Costa, 2016); ecologic villages (Borelli, 2014); changes in coffee consumption practices (Teixeira, 2014); dematerialization of digital media (Maggauda, 2011); and energy consumption (GramHanssen, 2010).

Levy and Weitz (2000) argue that the population's lack of time is a fact that forces companies to provide strategies to facilitate and expedite the consumption of goods they provide, as well as to use the idea of saving time embedded in the image of these products. According to Schatzki (2002), it is not only performance, but also the components or connectors of a practice that may change over time. And, since goods and services, and how they should be used, are part of the practices, consumption can also influence the trajectory of practices.

In their study, Hirschman et al. (1998) found that instant powder served very well as a second choice for most consumers with the benefit of being prepared individually without further difficulty. Soluble coffee found space among Brazilians due to some of its attributes, such as practicality, but it failed in features valued by consumers, such as the remarkable aroma and flavor (Teixeira, 2014). This practice can be completely replaced by the capsules that present the practicality characteristics of the preparation of the soluble coffee, conserving the aroma and flavor of the conventional preparations (Teixeira, 2014).

We observed that consumers initially adopt the technology of capsules by influence of their social sphere, sometimes before even experiencing the product. As Warde (2005) inferred, the demand for goods can often be generated indirectly, as when new tools or techniques require complementary products for their effective adoption, or when already established products are adopted in the performance of practices that previously did not use them. It is exactly at this point that the capsule machines and all their artifacts that instigate consumption come in: the need to organize their capsules instigates consumers to search for artifacts, whether they come from recognized brands or not, and in some cases it leads to the consumption of more capsules in order to contribute to the practice. Considering the single cup format was not considered a proxy for coffee quality, we can say that coffee capsules consumption is, simultaneously, a practical option and part of a wider practice.

According to Warde (2005), the satisfaction of desires relates not only to consumption, but to practices and their good performance. Consumption simply contributes in obtaining a variety of rewards associated with a practice. Thus, we can say that the coffee capsule consumption is surrounded by several practices, bounded by the artifact, i.e. the capsule coffee machine, which is nothing more than a product that, somehow, facilitates the practice of drinking coffee, pointing out the fact that consumption is not a practice itself, but it is a moment in almost every practice (Warde, 2005).

We found relations in coffee capsules consumption and the specificities that structure this market and guide consumption behavior. In this sense, this paper corroborated the theoretical field of practice and its adherence to consumer behavior. In addition, this research may be used as inspiration to market strategies in the segmentation of coffee capsules

As a limitation of this study, we stem from the possibility of generalizing our sample of 18 interviews. Also, it is important to mention the homogeneous professional occupation of the interviewees.

Finally, as a suggestion for future studies, we recommend to expand this work to a quantitative perspective, based on the elements already identified in this study. In this way, the results can be used to characterize the profile of consumers and the specificities of this market segment. For instance, statistical methods (descriptive and analytical) should be used to identify differences in their consumption practices. 


\section{References}

Alencar, E. (1999). Introdução à metodologia de pesquisa social. Lavras: UFLA.

Bardin, L. (2010). Análise de conteúdo. Lisboa: Edições 70.

Barribal, K. L., \& While, A. (1994). Collecting data using a semi-structured interview: a discussion paper. Journal of advanced nursing, 19(2), 328-335. doi. 10.1111/j.13652648.1994.tb01088.x.

Borelli, F. C. (2014). Consumo responsável sob a perspectiva prático-teórica: um estudo etnográfico em uma ecovila (Tese de Doutorado). Instituto de Pós-Graduação e Pesquisa em Administração - Coppead, Universidade Federal do Rio de Janeiro, Rio de Janeiro, RJ, Brasil.

Bourdieu, P. (1984). Distinction: A social critique of the judgement of taste. London: Routledge.

Carrêlo, M. V. P. (2014). A influência da marca Nespresso no comportamento de compra da máquina e cápsulas de café (Dissertação de Mestrado). Escola Superior de Comunicação Social, Lisboa - Portugal.

Costa, A. P. (2016). O Comportamento De Consumo De Corredores De Rua: Uma Abordagem Baseada Na Teoria Da Prática (Tese de Doutorado). Universidade Federal de Lavras, Lavras, MG, Brasil.

Dagevos, H., \& Van Ophem, J. Food consumption value: developing a consumer-centred concept of value in the field of food. British Food Journal, 115(10), 1473-1486. doi. 10.1108/BFJ-06-2011-0166.

Euromonitor International. (2015). Participação de mercado das cápsulas (\% do valor das vendas totais no varejo). In: EUROMONITOR INTERNATIONAL. Euromonitor Passport Database. 2015. Disponível em: <http://www.euromonitor.com/coffee_globalbriefing $>$. Acesso em: 22 mar. 2015.

Federação das Indústrias do Estado de São Paulo/ Instituto de Tecnologia de Alimentos. (2010). Brasil Food Trends 2020: relatório técnico. Recuperado de: http:/ /www. brasilfoodtrends.com.br/Brasil_Food Trends/index.html

Fonseca, A. B., Souza, T. S. N., Frozi, D. S., \& Pereira, R. A. (2011). Modernidade alimentar e consumo de alimentos: contribuições sócio-antropológicas para a pesquisa em nutrição. Ciência \& Saúde Coletiva, 16(9), 38533862.
Cidade alemã proíbe cápsulas de café em repartições públicas. G1 (2016, February 24). Retrieved from: http:// g1.globo.com/mundo/noticia/2016/02/cidade-alemaproibe-capsulas-de-cafe-em-reparticoes-publicas.html

Gandia, R. M., Sugano, J. Y., Vilas Boas, L. H. de B., Ferreira, C. A. \& Carvalho, E. G. (2016). Encapsulando Valores: um Estudo sobre a Influência das Marcas e a Estrutura dos Valores Que Orientam a Compra de Máquinas de Bebidas em Cápsulas. XL ENANPAD. Anais em CD. Costa do Sanipe/BA: Anpad. Setembro.

Gasparin, G. Veja diferenças entre definições de classes sociais no Brasil. G1 (2013, August 20). Retrieved from: http://g1.globo.com/economia/seu-dinheiro/ noticia/2013/08/veja-diferencas-entre-conceitos-quedefinem-classes-sociais-no-brasil.html

Giddens, A. (2009). A constituição da sociedade. São Paulo: Martins Fontes.

Gil, A. C. (1999). Métodos e técnicas de pesquisa social (2nd ed.). São Paulo: Atlas.

Gram-Hanssen, K. (2010). Standby consumption in households analyzed with a practice theory approach. Journal of Industrial Ecology, 14(1), 150-165. doi. 10.1111/j.1530-9290.2009.00194.x.

Gronow, J., \& Warde, A. (2001). Ordinary Consumption. London: Routledge.

Halkier, B., \& Jensen, I. (2011). Methodological challenges in using practice theory in consumpition research: examples from a study on handling nutritional contestations of food consumption research.

Journal of Consumer Culture, 11(1), 101-123. doi. $10.1177 / 1469540510391365$.

Hargreaves, T. (2008). Making pro-environmental behavior work: an ethnographic case study of practice, process and power in the workplace (PhD in Environmental Sciences). University of East Anglia, Norwich, United Kingdom.

Hirschman, E. C., Scott, L., \& Wells, W. B. (1998). A model of product discourse: linking consumer practice to cultural texts. Journal of Advertising, 27(1), 33-50.

Levy, M., \& Weitz, B. (2000). Administração de varejo. São Paulo: Atlas.

Lima, A. C. C. (2015). Responsabilidade Social Empresarial e Stakeholders Vulneráveis: um estudo de caso sobre a Usina Hidrelétrica do Funil na visão de atingidos (Dissertação de mestrado). Universidade Federal de Lavras, Lavras, MG, Brasil. 
Lowe, M. R., Bocarsly, M. E., \& Parigi, A. Human eating motivation in times of plenty: biological, environmental and psychosocial influences. In: Harris, R. B. S, \& Mattes, R. D. (Ed.). Appetite and Food Intake: Behavioral and Physiological Considerations (Chapter 6, 95-112). Boca Raton: CRC Press.

Magaudda, P. (2011). When materiality 'bites back': digital music consumption practices in the age of dematerialization. Journal of Consumer Culture, 11(1), 15-36. doi. 10.1177/1469540510390499.

Malhotra, N. K. (2012). Pesquisa de Marketing: Uma Orientação Aplicada (6th edition). Porto Alegre: Bookman.

Martins, M. C. F. (2013). Atitude relativamente à máquina de café em cápsula: estudo sobre razõos de compra (Tese de Doutorado). Instituto Politécnico de Lisboa, Lisboa, Portugal.

Matters, R. D. (2008). Appetite and Food Intake: behavioral and physiological considerations. Boca Raton: CRC Press.

Mozzato, A. R., \& Grzybovski, D. (2011). Análise de conteúdo como técnica de análise de dados qualitativos no campo da administração: potencial e desafios. Revista de Administração Contemporânea, 15(4), 731-747. doi. 10.1590/ S1415-65552011000400010.

Práticas, cápsulas de café feitas de plástico podem representar risco ambiental e à saúde. Ecycle (n.d.). Retrieved from: http://www.ecycle.com.br/component/ content/article/62/2243-praticas-capsulas-de-cafe-feitasde-plastico-podem-representar-risco-ambiental-e-a-saude. $\underline{\mathrm{html}}$

Reckwitz, a. (2002). Toward a Theory of Social Practices: A Development in Culturalist Theorizing. European Journal of Social Theory, 5(2), 243-263. http://doi. org/10.1177/13684310222225432

Santos, D., Araújo, J. R., França, L. C. L., \& Paula, M. F. R. (2016). Fatores críticos de competitividade na cadeia produtiva do café no Brasil e o mercado de cápsulas de café. Jovens Pesquisadores - Mackenzie, 12(1), xx-xx. doi.

Schatzki, T. (2002). The Site of the Social: A Philosophical Exploration of the Constitution of Social Life and Change.

University Park: The Pennsylvania State University Press.

Silva, C. R., Gobbi, B. C., \& Simão, A. A. (2005). O uso da análise de conteúdo como uma ferramenta para a pesquisa qualitativa: descrição e aplicação do método. Organizações Rurais \& Agroindustriais, 7(1), 70-81.
Swann, G. M. P. (2002). There's more to economics of consumption than (almost) unconstrained utility maximization. In: McMeekin, A., Tomlinson. M, Green, K., \& Walsh, V. (Orgs). Innovation by the demand: An interdisciplinary approach to the study of demand and its role in innovation (Chapter 3, pp. 23-41). Manchester: Manchester University Press.

Teixeira, A. P. P. (2014). Do coador de pano à cápsula: as mudanças nas práticas de consumo de café no Brasil nos últimos 50 anos (Dissertação de mestrado). Universidade do Vale do Rio dos Sinos - UNISINOS, São Leopoldo, RS, Brasil.

Warde, A. (2005). Consumption and theories of practice. Journal of Consumer Culture, 5(2), 131-153. doi. 10.1177/1469540505053090. 